\title{
FEASIBILITY STUDY OF CONCRETE BASED PAVEMENT BY USING FIBERS \& CEMENTING WASTE MATERIALS
}

\author{
Abhinav S. Pawar ${ }^{1}$, K.R. Dabhekar ${ }^{2}$ \\ ${ }^{1}$ PG student M-tech Transportation Engineering, GHRCE, Nagpur, Maharashtra, India \\ ${ }^{2}$ Asst.Professor Civil Engineering Department GHRCE Nagpur, Maharashtra, India
}

\begin{abstract}
The main purpose of this investigation is to study the behavior of rigid pavement (concrete) which occurs when cementing waste material (GGBS) and steel fibers are added and to compare with normal concrete of M40 grade. For this study, concrete cubes and beams were produced of five partial GGBS replacement ratios (10\%, 20\%, 30\%, 40\% and 50\%) with constant water-cement ratio (0.37) and cement dose of $486 \mathrm{~kg} / \mathrm{m}^{3}$. To keep a constant workability, super plasticizer was used in concrete. The cubes and beams were tested at the age of 7,28 and 56 days with continuous water curing condition. The comparison between normal concrete, GGBS concrete and with steel fiber concrete was made. After testing it was found that at 30\% GGBS replacement we can get M40 strength of concrete. But flexural strength decreases by increasing percentage of GGBS so that to increase in flexural strength steel fibers of two different aspect ratios (7560 \& 7530) was used. Steel fibers were added in concrete by $1 \%$ of total weight of concrete with different proportions. Thus the compressive and flexural strength reached up to considerable limit.
\end{abstract}

Keywords: GGBS, Steel Fibers, concrete.

\section{INTRODUCTION}

In India, we produce about 7.8 million tons of Ground Granulated blast furnace slag as a bye product obtained in the manufacture of pig iron in the blast furnace. It is a nonmetallic product consisting essentially of silicates and aluminates of calcium and other bases. The molten slag is rapidly chilled by quenching in water to form a glassy sand like granulated material. The disposal of such slag even as a waste fill is a problem and may cause serious environmental hazards with the projected economic growth and development in the steel industry, the amount of production is likely to increase many folds and environmental problem. It is seen that high volume eco-friendly replacement by such slag leads to the development of concrete which not only utilizes the industrial wastes but also saves a lot of natural resources and energy. This in turn reduces the consumption of cement

\section{EXPERIMENTAL PROGRAM}

Compressive strengths and flexural strengths of specimens with various percentage replacement of cement with GGBS is determined by casting concrete cubes of size $150 \mathrm{~mm} \mathrm{X}$ $150 \mathrm{~mm} X 150 \mathrm{~mm}$ and beams of size $100 \mathrm{~mm} \mathrm{X} 100 \mathrm{~mm} \mathrm{X}$ $500 \mathrm{~mm}$ and testing them after 7,28 and 56 days of curing. Concrete use was standard (M40) grade of concrete mix.
-***

\section{CONCRETE MIX DESIGN}

As per IS 10262:2009 (recommended guidelines for concrete mix design) concrete mix design was made for M40. Table 1 shows the mix proportion for M40 mix.

Table 1 - Quantity for $1 \mathrm{~m}^{3}$ concrete

\begin{tabular}{|l|l|l|}
\hline 1 & Cement & $486 \mathrm{Kg}$ \\
\hline 2 & Water & $18 \mathrm{Kg}$ \\
\hline 3 & Fine aggregate & $435 \mathrm{Kg}$ \\
\hline 4 & Coarse aggregate & $1305 \mathrm{Kg}$ \\
\hline 5 & Chemical admixture & $2.43 \mathrm{Kg}$ \\
\hline
\end{tabular}

Table 2- Compressive strength of concrete at different ages.

\begin{tabular}{|l|l|l|l|l|}
\hline Sr.no & GGBS & \multicolumn{3}{|l|}{$\begin{array}{l}\text { Compressive strength } \\
(\mathrm{MPa})\end{array}$} \\
\hline & $(\%)$ & 7 days & 28 days & 56 days \\
\hline 1 & 0 & 36.5 & 46.90 & 48.01 \\
\hline 2 & 10 & 32.98 & 44.66 & 46.50 \\
\hline 3 & 20 & 30.83 & 43.74 & 46.10 \\
\hline 4 & 30 & 27.03 & 43.10 & 47.24 \\
\hline 5 & 40 & 22.95 & 35.40 & 38.47 \\
\hline 6 & 50 & 16.88 & 26.44 & 28.78 \\
\hline
\end{tabular}


Compressive strength of concrete at different ages.

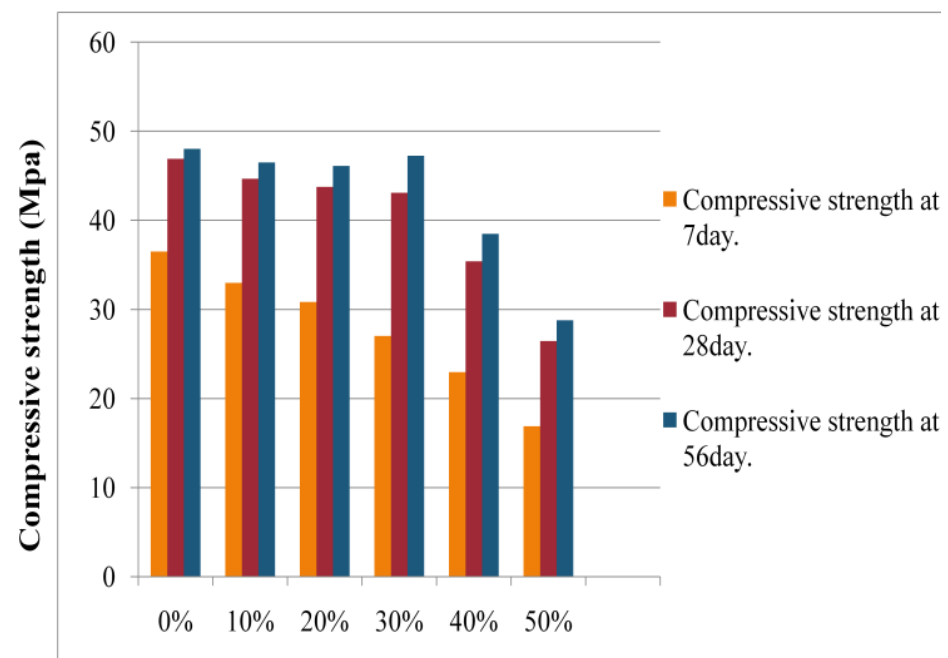

Percentage of GGBS (\%)

Graph.2

Table 3- Flexural Strength of Concrete at different ages.

\begin{tabular}{|l|l|l|l|l|}
\hline $\begin{array}{l}\text { Sr.n } \\
\text { o }\end{array}$ & GGBS & \multicolumn{3}{|l|}{$\begin{array}{l}\text { Flexural Strength } \\
(\mathrm{MPa})\end{array}$} \\
\hline & $(\%)$ & 7 days & 28 days & 56 days \\
\hline 1 & 0 & 5.21 & 6.47 & 6.80 \\
\hline 2 & 10 & 4.81 & 6.01 & 6.36 \\
\hline 3 & 20 & 4.48 & 5.18 & 5.55 \\
\hline 4 & 30 & 3.89 & 4.34 & 5.09 \\
\hline 5 & 40 & 2.6 & 3.61 & 4.27 \\
\hline 6 & 50 & 1.57 & 2.56 & 3.23 \\
\hline
\end{tabular}

Flexural Strength of Concrete beams at different ages.

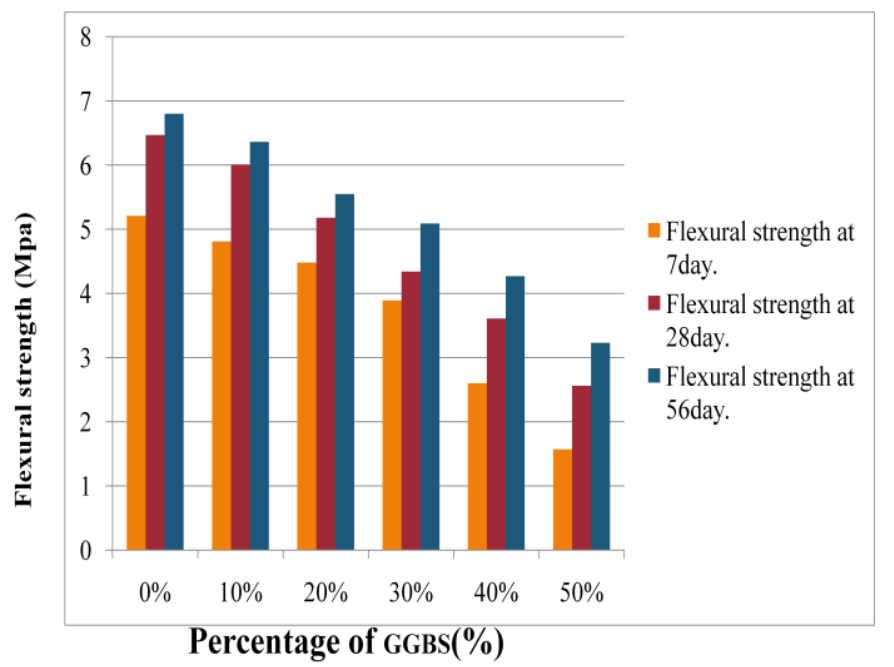

Graph 3
Table.4-Compressive Strength of Concrete at different ages Using (Steel Fibers+ 30\%GGBS)

\begin{tabular}{|l|l|l|l|l|}
\hline $\begin{array}{l}\text { Sr.n } \\
\mathrm{o}\end{array}$ & GGBS & \multicolumn{3}{|l|}{$\begin{array}{l}\text { Compressive Strength } \\
(\mathrm{MPa})\end{array}$} \\
\hline & $(\%)$ & 7 days & 28 days & 56 days \\
\hline 1 & $\begin{array}{l}0.25 \& \\
0.75\end{array}$ & 28.81 & 45.13 & 49.16 \\
\hline 2 & $0.5 \& 0.5$ & 34.59 & 49.77 & 51.18 \\
\hline 3 & $0.75 \& 0.25$ & 29.27 & 45.44 & 49.26 \\
\hline 4 & $1 \%(7530)$ & 28.60 & 45.49 & 49.52 \\
\hline 5 & $1 \%(7560)$ & 27.98 & 45.03 & 49.10 \\
\hline
\end{tabular}

Compressive Strength of Concrete Cubes at different age Using (Steel Fibers + 30\%GGBS)

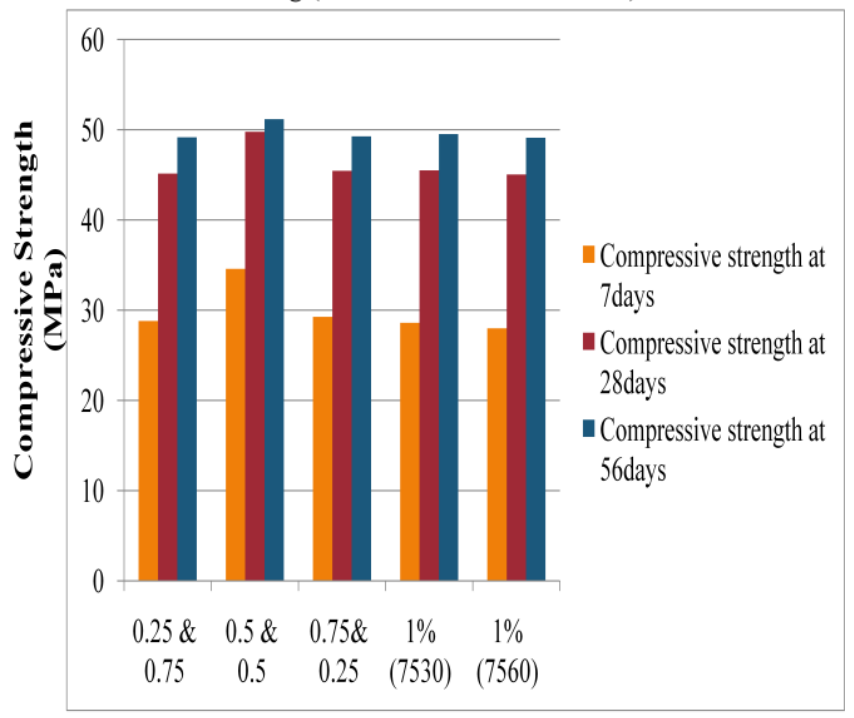

Steel Fiber Percentage $(\%)$

\section{Graph 4}

Table 5- Flexural Strength of Concrete at different ages Using (Steel Fibers+ 30\%GGBS)

\begin{tabular}{|l|l|l|l|l|}
\hline $\begin{array}{l}\text { Sr.n } \\
\mathrm{o}\end{array}$ & GGBS & \multicolumn{3}{|l|}{$\begin{array}{l}\text { Flexural Strength } \\
(\mathrm{MPa})\end{array}$} \\
\hline & $\%)$ & 7 days & 28days & 56 days \\
\hline 1 & $\begin{array}{l}0.25 \& \\
0.75\end{array}$ & 4.48 & 6.72 & 7.46 \\
\hline 2 & $0.5 \& 0.5$ & 5.36 & 7.27 & 7.92 \\
\hline 3 & $0.75 \& 0.25$ & 4.72 & 6.95 & 7.55 \\
\hline 4 & $1 \%(7530)$ & 4.44 & 6.73 & 7.51 \\
\hline 5 & $1 \%(7560)$ & 5.00 & 7.16 & 7.87 \\
\hline
\end{tabular}




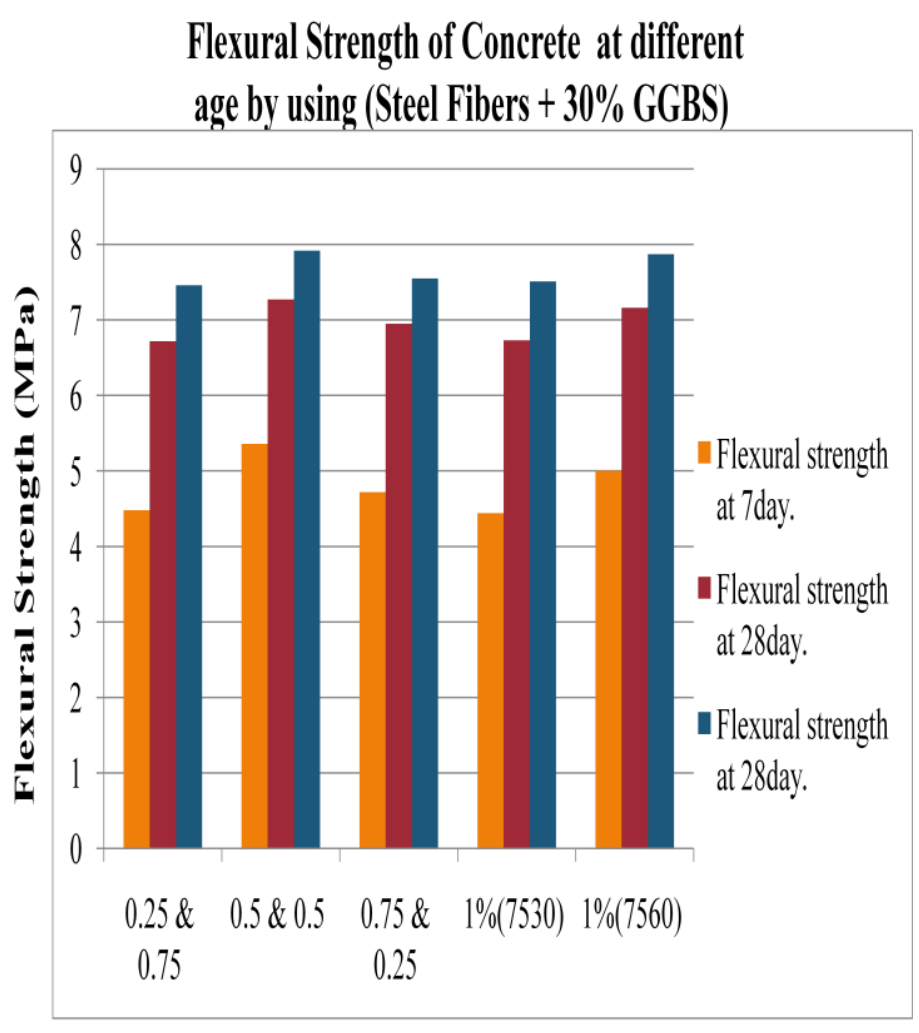

Steel Fiber Percentage $(\%)$

\section{Graph 5}

\section{CONCLUSIONS}

The following conclusions can be drawn from the experimental investigations conducted on the behavior of concretes with GGBS as partial replacements for cement-

1) With increase in percentage of G.G.B.S the flexural and compressive strength of concrete decreases.

2) With maximum $30 \%$ percent replacement of GGBS with cement the strength of concrete is found at considerable limits.

3) It was also observed that the early strengths (up to 28 days) of concrete mix (with 10\%, 20\%, 30\%, 40 and $50 \%$ GGBS replacements) were lower than that of Portland cement concrete mixes.

4) By 56 days, the strength of $30 \%$ GGBS mix exceeded that of the $10 \%, 20 \%, 40 \%, \& 50 \%$ GGBS mixes.

\section{REFERENCES}

[1] M. Regourd, J.H. Thomassin, P. Baillif, J.C. Touray, "Blast-furnace slag hydration: surface analysis", Cem. Concr. Res. 13 (4) (1983) 549-556.

[2] OzkanSengul and Mehmet Ali Tasdemir; "Compressive Strength and Rapid Chloride Permeability of Concretes with Ground Fly Ash and
Slag" Journal of Materials in Civil Engineering, 2009.21:494-501.

[3] Yeau KY, Kim EK. "An experimental study on corrosion resistance of concrete with ground granulateblast-furnace slag", Cement Concrete Res 2005;35:1391-9.

[4] Song HW, Saraswathy V. "Studies on the corrosion resistance of reinforced steel in concrete with ground granulated blast-furnace slag - an overview" J Hazard Mater 2006;B138:226-33.

[5] Jau WC, Tsay DS. "A study of the basic engineering properties of slag cement concrete and its resistance to sea water corrosion"CemConcr Res 1998;28(10):136371.

[6] Pal SC, Mukherjee A, Pathak SR. "Corrosion behaviour of reinforcement in slag concrete" ACI Mater J 2002;99-M52:521-7.

[7] American Concrete Pavement Association (2006) Concrete Pavement Progress [online] available from <http:/ www.pavement.com

[8] Road surfacing (2000). Journal of Highways and Public Work 69, (4) 13-14.

[9] Zhang and Monotonic, "Fatigue performance in bending of fibre-reinforced engineered cementitious composite in overlay system", Journal of Cement and Concrete Research, 2002 32,(9) 415-423.

[10] Janet, M.L. and J.B. Cris, "Experimental study of Influence of bond on flexural behavior of concrete beams pretensioned with Aramid fibre reinforced plastics”,ACI structural Journal 9, (3) 377-386.

\section{BIOGRAPHIES}

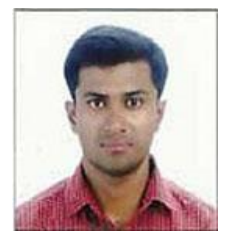

Mr.Abhinav S. Pawar, PG Student M-tech Transportation Engineering, GHRCE, Nagpur, Mahatrashtra, India

Mr. Kuldeep R. Dabhekar, Asst. Professor GHRCE, Nagpur, Maharashtra, India 